\title{
The Analysis of Different Characterizations Between Daisy and Jordon in The Great Gatsby From the Feminist Perspective
}

\author{
QIAN Dan \\ Ningbo Dahongying University, Ningbo, Zhejiang, China
}

\begin{abstract}
This paper is trying to analyze different characterizations between Daisy and Jordon from feminist perspective to throw light on the images of Daisy and Jordon in The Great Gatsby, portraying two different kinds of women with different ideas created by F. Scott Fitzgerald at the background of the patriarchal society, Daisy stands for a traditional oppressed woman whereas Jordan represents a new female image in pursuit of freedom and independence. Simultaneously, their images also reveal an inspiring implication for women who want to obtain independence and freedom, only when women break the shackles of patriarchal ideology and gain the independence of economy by unremitting efforts can they completely enjoy the independence of mind as well as the right that they deserve.
\end{abstract}

Keywords: different characterizations, feminist, patriarchal society

\section{Introduction}

Francis Scott Key Fitzgerald, one of the most illustrious writers in American literature in the 1920s, is widely acclaimed as chronicler and laureate of the Jazz Age. In his fleeting life, he offered a large number of novels and short stories to the American literature, such as This Side of Paradise, The Beautiful and Damned and Tender Is the Night. Among all his works, the most well-known one is The Great Gatsby published in 1925 which established his position in the history of modern American literature and has enjoyed popularity among plenty of scholars until now. This work primarily concerns the tragic love between the well-off man Jay Gatsby and his beautiful former lover Daisy Buchanan. Equally important, it shapes several distinctive characters, among which Daisy and Jordon are two inevitable characters who represent two kinds of typical women. Meanwhile, feminism almost has captured world's attention recently. Considering this work is imbued with male consciousness by a male narrator at the background of patriarchal society, it is essential to analyze the different characterizations between Daisy and Jordon from feminist perspective. Daisy embodies a traditional oppressed woman while Jordan represents a new female image in the "Jazz Age" with feminist consciousness which few of women possess, likewise, both of whom imply the two ideological trends in that time.

\section{Literature Review}

Owing to the prompt development of the feminist in the west of the world, it is necessary and significant to analyze the most of the female characters in male writer's novels. As vital and indispensable roles in The Great Gatsby, Daisy and Jordon have long been enjoyed popularity among people for a long time, and

QIAN Dan, Undergraduate, Ningbo Dahongying University. 
researches also have been carried out by plenty of scholars in various fields all around the world.

Curnutt (2007) points out that the Daisy is extremely irresponsible in Nick's eye whereas she is so gorgeous in Gatsby's eye, so it is impossible for us to understand her in such contradiction. Cooperman (1996) describes Jordan Baker is a career woman who is aped in sport, as a matter of fact, her name was designed by Fitzgerald to show her personality. During one period, Jorden and Baker are "two well-known automobiles of the period - the Baker, electric car, and the sporty Jordan, and thus in some way, she is a commodity herself" (Cooperman, 1996, p. 60). Kate Millett (1970) argues that male writers distort the images of women in their dominated culture and the literature, showing signs of gender discrimination. Literature reflects the social ideology, so the writer's understanding of the relationship between the two sexes is significantly influenced by the patriarchal ideology. Only change the mode of literary criticism can we structure and reappear the real images of women, raising the awareness of female readers. Nevertheless, it is difficult to thoroughly clear the ingrained sexual politics. Dalton Gross (1998) assumes that for women, generally speaking, marriages are the only jobs they can get, whether they marry and whom they are going to marry have a bearing on economic necessity. Professor Wu Jianguo (2002) believes that Daisy possesses her own rules of survival and characteristics, yet she also lives in Gatsby's fantasy. In real life, she is a person of no ideal, sincere, sentiment, who only regards enjoying life as the highest goal. But in the spiritual world of Gatsby, she is the supreme and wonderful dream that embodies all the beautiful things. Yang Lixin (2000) holds that as the basis of human reproduction and the half of the human population, women play irreplaceable roles in it. Nonetheless, their roles in the economy, politics and society have always been ignored and reduced and suppressed. Apart from the pressure of race and rank, they have to endure many stresses coming from man world.

Taking all the factors into account, the researches of both in abroad and home have made great progress, which exert an irreplaceable influence on the development of these researches. Meanwhile, it also paves a better way for the later explores. Nevertheless, they do not have further study on the comparison of characterizations between Daisy and Jorden. On the basis of these, I focus on comparing and analyzing the different characterizations between Daisy and Jordon in The Great Gatsby from feminist perspective, making the research more in-depth and diverse.

\section{The Definition of Feminism}

Increasingly burgeoning in recent years, feminist is widely used in literature studies, providing a unique and new perspective for people to analyze and study literature. Feminism usually refers to the theories that women should be legitimized by law, and should have equal rights and opportunities in all fields like men do, which originated from fighting for women's rights in Europe in the last century. In the literature world, it means the criticism of male centralism in traditional culture, condemns the patriarchal consciousness in male-dominated literary works, thus promoting the self-consciousness of women and gender equality. According to historical moment and other factors, the modern Western feminist movements are divided into three periods and feminists around the world have different causes and goals. In the first period, women demanded the equal economic and political rights that they deserved. In addition, under the influence of the first feminist movement, feminism gradually became a kind of independent theory and criticism method in 1950. In the second period, although the feminist achieved significant results in the political and economic fields, their unequal status had not been fundamentally improved. Therefore, they had to focus on the theoretical construction, and finally created three unique feminist theories which were Free Feminism, Socialist 
Feminism and Radical Feminism. During the third period, on the basis of the reflections of the former two periods and solutions of other newly emerged issues, the post-modern feminism tried to improve and perfect itself gradually.

\section{The Different Characterizations Between Daisy and Jordon From Feminist Perspective}

Generally speaking, the different characterizations between Daisy and Jordon can be manifested in the following aspects: such as the differences on mentalities; the differences on behaviors; the differences on speeches.

\section{The Differences on Mentalities}

In a large extent, feminine consciousness is part and parcel in women's ideologies that largely refers to women's sense of themselves and is considered the prerequisite in the spirit to pursue freedom and equality. Daisy shows embryonic feminine consciousness in the early stage but later is strangled by the ruthless shackles of patriarchal society whereas Jordon is against that with feminist consciousness and spirit of revolt, essentially and thoroughly.

When Gatsby has to rush to the overseas, Daisy, a great lady from upper-class, even wants to see him off but finally is prevented by her family intensely. Later she does not talk to the family for a few weeks, which obviously violates the criterion of the patriarchal system. In addition, the day before wedding, she refuses to marry Tom. She is convinced that Gatsby would come to prove that all she does is right. However, Gatsby's congratulations in a letter wreaks havoc on her conviction, gives her a deep sense of being abandoned to such an extent that adversely impinges on her embryonic feminine consciousness, thus making her become a doomed woman to be arranged.

Simone De Beauvoir (1972) points out in The Second Sex that unlike men, a girl in puberty is waiting for the coming of a new period which is difficult to predict. She is passive, for the realization and extrication from her fate depending on men. Then, looking for a husband, or sometimes finding a protector, is one of the most important tasks for her (De Beauvoir, 1972). Due to no sources of income and no support of her initial conviction, Daisy feels insecure and weak. Consequently, she is forced to be arranged by her family to marry Tom, so as to survive in the society and, more significantly, look for a spiritual sustenance via depending on her well-to-do husband. After three months of her honeymoon, she utterly relies on Tom both economically and spiritually. "She used to sit on the sand with his head in her lap by the hour rubbing her fingers over his eyes and looking at him with unfathomable delight" (Fitzgerald, 1925). It seems that what fate she must grasp is her marriage, for that can ensure her a stable life. In patriarchal society, most of the women do not acquire the economic independence, let alone spiritual independence. The patriarchal society does keep a tight rein on her mind, thrashing her consciousness of being independent spiritually. Therefore, as a traditional passive woman with airy mind, Daisy has no alternatives to be controlled by her husband both economically and spiritually and does the way what traditional a woman usually does.

On the contrary, lacking of the ideological education from big family but an old aunt who never educates her, Jordon is not been controlled and stifled by traditional patriarchal culture in her mind. What is more, her decent job enables her to provide herself with necessary material conditions and lay a solid foundation for her spiritual independence. Such spiritual independence serves as prop to her firm faith of pursuing equality between men and women. Viewing Daisy's miserable, hapless and ill-fated marriage that exerts a detrimental effect on her, she is not hesitated to contribute to the reunion of Daisy and Gatsby in that she acutely knows the 
unfair fate and the predominant patriarchal society has inflicted the woman like Daisy with endless torment and untold suffering. The struggle in the society and the experience of an athlete mature her in the long run, making her be all the more aggressive and ambitious in her sports career. Admittedly, Jordon is the one of the few forerunners in a unique road to become an independent and strong-willed new woman, both economically and physically. She adheres to the faith that only when women control the economic sovereignty can they enjoy the right that she deserves, which is rarely grasped by other women.

\section{The Differences on Behaviors}

The beginning of the twentieth century witnessed the burgeoning women's liberation movement in America, especially in 1920, when women made the right to vote, the women's liberation movement reached its peak. This period was characterized by the emergence of the new women. These new women broke the grip of family, went to the work to obtain economic independence and marriage equality. Meanwhile, they are also keen on parties and sports, and even want to smoke as well as drink. At the beginning of the novel, when Nick enters the room to see Daisy and Tom, the thoroughly different behaviors of Daisy and Jordon are vibrantly delineated by their responses to Nick, which foreshadow the roads they take respectively. The Jordon on the couch firstly catches his attention. She was extended full length at her end of the divan, completely motionless and with her chin raised a little as if she were balancing something on it which was quite likely to fall. If she saw me out of the corner of her eyes she gave no hint of it (Fitzgerald, 1925). The moment that Nick comes into the room, she just indifferently glances at Nick without any words and continues to do her balance exercise. It seems that Jordon appears arrogant and nonchalant. In fact, she regards evading male instinctively at some point as a kind of self-protection of new women in their social circles with male in patriarchal society, for she does not identify the purpose of that man and unwilling to cater to man to knock down her esteem. Daisy matters family a lot while Jordan is obsessed with her own career and wins an excellent reputation by outstanding performance in the sports industry. Since she has to partake in the National Golf Championships, she lives in a life with no fixed abode, which is different from the traditional women who have to be confined in family. It is no wonder that she run across Tom and Daisy when they are on their honeymoon in France. Furthermore, once in the competition, she violates the working ethics by removing the ball from the disadvantageous position but she retorted that she does not. It is not so much a dishonest as a strong control on the things and ambition in the light of the background of the society is a man-dominated one. Undoubtedly, she represents a new woman different from the conservative ones, who is ready to compete with the male with her intelligence in patriarchal society.

Unlike Jordon, Daisy leans faintly forward to talk to him in her low, thrilling voice. It was the kind of voice that the ear follows up and down as if each speech is an arrangement of notes that will never be played again. There was an excitement in her voice that men who had cared for her found difficult to forget (Fitzgerald, 1925).

Living in a prosperous life from an upper-class family, she has been inculcated by her family with old-style family rite since she was young. In the long run, she has internalized the traditional evaluation standard of the patriarchal society to the women. Daisy, like most of the common traditional women in the patriarchal society, tends to use her gentle as well as seductive voice to attract men, undoubtedly leaving a remarkable and unforgettable impression on man. Therefore, it is not so much a pretentious demeanor as a habit. Admittedly, she is no other than the epitome of the conventional women. What is more, she has to abide by the 
conservative social norms and ethics concerning the patriarchal society, which she is forced to do it. For instance, when her husband goes to pick up the phone from his mistress, she has to please the guests by telling the so-called family secret - the butler's nose in order to help Tom to conceal his affair and protect her husband's indignity. Similarly, if a woman divorced in that time, she would not be recognized and accepted by others in that society. So, that is the reason why Tom can overtly have affair with other women but she maintains a good reputation and never attends any parties. If she divorced and left her family with Gatsby, she would be denounced by the public and her good and spotless reputation she has built for years would be destroyed instantly.

\section{The Differences on Speeches}

To some extent, speeches can indirectly reflect one person's character. The different speeches on Daisy and Jordon graphically delineate their different attitudes toward their lives of outlooks and personalities.

After nick tells Daisy that a raft of people in Chicago wants to take their greetings to her, she feels extremely excited and happy, "Do they miss me?” she cried ecstatically. "How gorgeous! Let’s go back, Tom, Tomorrow!" (Fitzgerald, 1925). The moment when she looks at Nick, she compares Nick to a rose. "I love to see you at my table, Nick. You remind me of a — of a rose, an absolute rose. Doesn't he?” She turned to Miss Baker for confirmation (Fitzgerald, 1925). Sometimes she is a sentimental woman brimming with romance, other times she looks like an innocent and cute child with theatrical imagination. Throughout her life, she never endures any hardships and frustrations outside the home because her family offers her enough protection all the time so that she does not have the chances to struggle with others in a cruel society. Her speeches truly unfold a simple woman who always wants to articulate her feelings without hesitation. In a word, she is a more than emotional, romantic and outspoken woman in a large extent.

Nonetheless, being a distinctive image in the Jazz Age, Jordon is a very sophisticated and less emotional woman with strong personality. She once said to Nick, "It’s a great advantage not to drink among hard-drinking people. You can hold your tongue and, moreover, you can time any little irregularity of your own so that everybody else is so blind that they don't see or care” (Fitzgerald, 1925). Confronted with the sly and filthy people in the society, Jordon, an impotent woman compared with other men, has to do something that seems like immoral and unethical to protect herself. In other words, she is more like to gain the initiative to the things surrounding her and not willing to be in a disadvantage at any time, which vastly subverts the traditional female image. To all intends and purposes, independent and hardheaded as she is, she is clearly aware of her poor situation as women like her. "I was walking along from one place to another half on the sidewalks and half on the lawns” (Fitzgerald, 1925). When describing her journey of life, Jordan is quite sober and rational and she knows the road she takes is bound to be tough and rough, yet she has no option to do it.

\section{Conclusion}

Daisy and Jordon respectively represent two typical women with different outlook, which also symbolize two ideological trends in the patriarchal society. One is the wretched, oppressed, traditional woman while the other is the emerging woman after The First World War in the "Jazz Age". There are differences between their social relations, attitudes towards life and outlooks of life. At the meantime, it also signifies the feminist ideological trend struggles with the male-dominated patriarchal culture. It can be concluded that women at any age should lay great emphasis on the independence and correct attitude towards freedom, getting rid of being controlled by the men and money. Only in this way can they enjoy fairness and gain the rights that they deserve. 
Moreover, the public also should pay much attention to the women's social status, so as to help them to know that they have the equal right as men and create a more harmonious society. If women want to pursue the equality, freedom and the right they deserve, the key lies in that they should achieve the independence economically and spiritually.

\section{References}

Curnutt, K. (2007). The Cambridge introduction to F. Scott Fitzgerald. Cambridge: Cambridge University Press.

Cooperman, S. (1996). F. Scott Fitzgerald's The Great Gatsby. Beijing: Foreign Language Teaching and Research Press.

Donaldson, S. (1984). Critical essays on F. Scott Fitzgerald's The great Gatsby. Boston: G.K. Hall and Co.

De Beauvoir, S. (1972). The second sex. London: Penguin.

Fitzgerald, F. S. (1994). The Great Gatsby. New York: Penguin Popular Classics.

Gross, D., \& Gross, M. J. (1998). Understanding the Great Gatsby: A student casebook to issues, sources, and historical documents. Westport, CT: Greenwood Press.

Millett, K. (2000). Sexual politics. Champaign: University of Illinois Press.

Prigozy, R. (2002). The Cambridge companion to F. Scott Fitzgerald. New York: Cambridge University Press.

Sanderson, R. (2002). Women in Fitzgerald's fiction. Cambridge: Cambridge University Press. 